Biological and Applied Sciences

Vol.59: e16160040, January-December 2016 http://dx.doi.org/10.1590/1678-4324-2016160040 ISSN 1678-4324 Online Edition

BRAZILIAN ARCHIVES OF BIOLOGY AND TECHNOLOGY

AN INTERNATIONAL JOURNAL

\title{
A Histological Study on Venom Apparatus of Montivipera xanthina (Gray, 1849) (Serpentes, Viperidae)
}

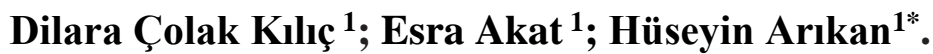 \\ ${ }^{I}$ Ege University-Ege University, Science Faculty, Biology Department, Bornova-Izmir, TURKEY
}

\begin{abstract}
This is the first report describing morphological and histological structure of venom apparatus in Montivipera xanthina. The venom gland apparatus of $M$. xanthina was composed of four distinct parts, main venom gland, primary duct, accessory gland and secondary duct. The main venom gland was composed of acini. The accessory gland was formed by long and ramified tubules. Nine fangs were detected in one half of the upper jaw each at different stage of development. Only one tooth was functional and the eight remaining fangs form a replacement series. The venom apparatus of viperid snakes are the most effective venom-delivery system among vertebrates and have been the focus of scientific interests for many years. Despite this interest, there are few studies including venom-delivery system of venomous snakes. The results presented here may be common among venomous snakes and model of the viperid design of the venom apparatus.
\end{abstract}

Key words: Montivipera xanthina, venom gland, fang, dentine, odontoblast

*Authors for correspondence: esra.akat@ege.edu.tr 


\section{INTRODUCTION}

The oral glands are varied in reptiles. They lie along the upper and lower lips, they are also located in opposite and beneath of tongue, nearby of nasal cavity or at temporal region and release their secretions into the oral cavity (Kardong 2002). Although the oral glands have the wide range of biological roles, the suite of oral glands in snakes contribute to successful prey capture, swallowing and digestion (Kochva 1978; Kardong 2002; Mackessy 2010).

In snakes, the infralabial and supralabial glands, venom and Duvernoy's glands are among the bestknown oral glands (de Oliveira et al. 2008). Although true venom gland and Duvernoy's gland are considered to be homologous, these glands have morphological and functional differences. True venom glands consist of main venom gland and accessory gland. These two glands are connected with primary duct. Venom gland holds a large store of ready venom which is injected as a high-pressure pulse via hollow fangs. Generally, accessory gland is absent in Duvernoy's gland, emptying is under low-pressure flow, and the secretion is not transported via hollow fangs (Kochva et al. 1967; Kardong 2002).

Fangs are important part of venom-delivery system, through which the venom passes. Two different hypotheses have been proposed to explain the formation of venom canal at the center of the fang. The mainstream hypothesis is the infolding hypothesis which suggests that the venom canal develops owing to the invagination of the epithelial wall of the developing tooth germ. The other hypothesis is the brick chimney which suggests the venom canal develops directly related to dentine deposition as the tooth develops. Therefore the fang is formed from the tip to the base without any folding of the tooth surface. Because mineralization continues basally, the venom delivery canal is built as the formation of a hollow chimney (Edmund 1969; Jackson 2002; Zahradnicek et al. 2008).

Montivipera xanthina (Gray, 1849) is a venomous viperid species. The head is distinct from the neck, of triangular shape, and covered with small, keeled scales except supraocular plates. The dorsum is characterized by zig-zag pattern. M. xanthina is common viper species found throughout Central, Southern and Western Anatolia and Greece as well as many of the Greek islands. Specifically, the most abundant species in Turkey (Budak and Göçmen 2005). The aim of this study was to investigate the morphological and histological characteristics of the venom apparatus in $M$. xanthina for a better understanding of the venom apparatus in frontfanged snakes.

\section{MATERIAL AND METHODS}

Two juvenile specimens (one male and one female) of $M$. xanthina were captured from İzmir/Turkey $\left(38.021056^{\circ} \mathrm{N}, 27.274583^{\circ} \mathrm{E}\right)$ in April. Animals were anaesthetized with ether, and euthanized by decapitation. For light microscopy, the venom apparatus was fixed in Bouin's fixative for $24 \mathrm{~h}$ at $4^{\circ} \mathrm{C}$. Tissue samples were processed according to the standard histological techniques for paraffin embedding. Thereafter five micrometers serial sections were stained with Mayer's hematoxylineosin (HE) and Mallory's trichrome (MT) and photographed using a Leica DM3000 microscope (Leica Microsystems) that was equipped with a Leica digital camera (DFC290).

\section{RESULTS AND DISCUSSION}

The paired venom apparatus was located on each side of head of $M$. xanthina. The venom apparatus was composed of a main gland, a primary duct, an accessory gland and secondary duct that joined the fang sheath (Fig 1). Generally a main venom gland, a primary duct (typically absent in elapids), an accessory gland, and a secondary duct leading to an enlarged maxillary fang, is typical venom apparatus of front-fanged snakes (Mackessy and Baxter 2006).

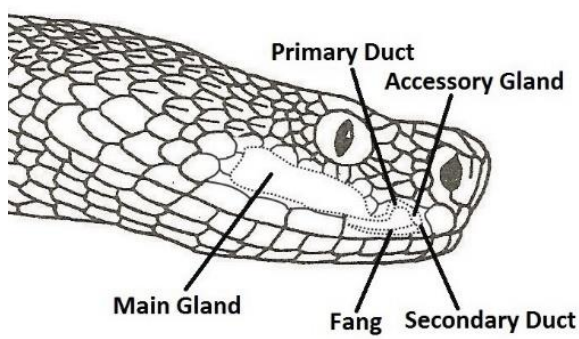

Figure 1. Diagram demonstrating location and parts of the venom apparatus in Montivipera xanthina (redrawn from Başoğlu and Baran 1980).

There is no differences between male and female venom apparatus in terms of histological characteristics. Main venom gland was covered with connective tissue capsule. In the main venom gland, secretory cells form clusters called acini, which are arranged in lobes separated by a thin 
fibrous barrier (Fig 2A) like in Duvernoy's gland of Natrix tessellata (Akat et al. 2011). Accessory gland was formed by long and ramified tubules. Loose connective tissue was observed throughout the intertubular area. The whole accessory gland was surrounded with dense regular connective tissue (Fig 2B). The histology of the accessory gland of $M$. xanthina was very similar to that of other viperid snakes (Kochva 1987; Mackessy 1991; Sakai et al. 2012). Gans and Kochva (1965) reported that the accessory gland secretion can keep the venom from draining continuously into the mouth of the snake. Although accessory gland is an internal reservoir for secretion (Kardong 2002), Gennaro et al. (1963) reported that the extract of accessory gland can increase toxicity of the venom from true venom gland due to the presence of a sulfated uronic acid containing polysaccharide.

Skeletal muscle has been included in both main venom gland and accessory gland capsule. The venom delivery system of viperid snakes is regulated by contraction of the compressor muscle (Young et al. 2001; Young and Kardong 2007). The accessory gland was covered with dense regular connective tissue due to fact that the passing venom to the fang by contraction of the compressor muscle can cause mechanical stress. Anterior region of the accessory gland and secondary duct that joined the fang sheath with numerous mucus secreting cells (Fig 2C) like goblet cells of vertebrate gastrointestinal tract and mucous glands of amphibian skin. The mucus acts to maintain moisture, lubrication and reduce mechanical friction (Lagow et al. 1999; Rogers 2003; Kim and Ho 2010; Akat et al. 2014 a,b). The main function of salivary mucus is to maintain tissue moisture, enable the lubrication thereby providing the integrity of the oral mucosa (Tabak 1995). All these functions may be attributed to mucus secreting cells in the fang sheath.

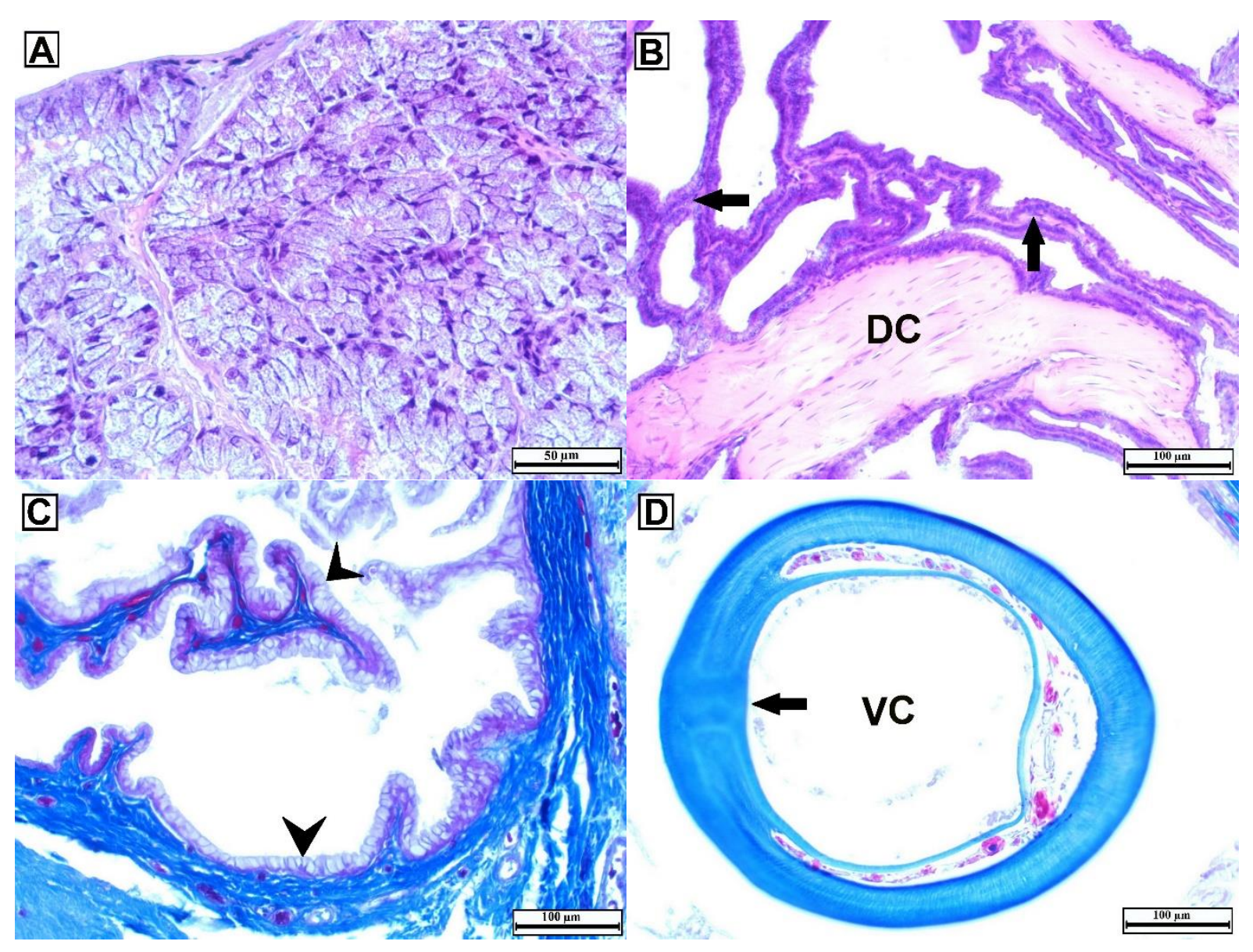




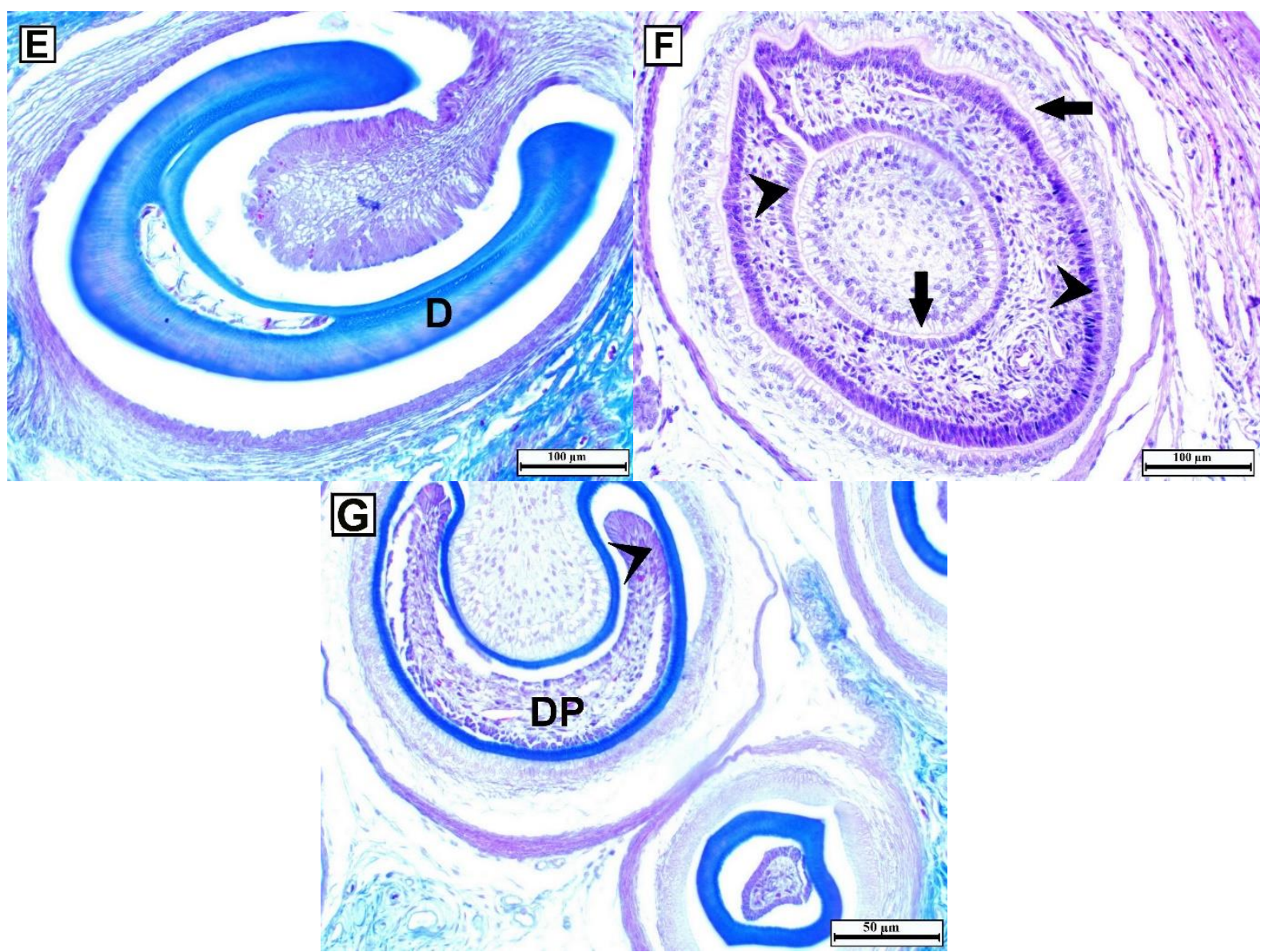

Figure 2. Light microscopic view of the venom apparatus of Montivipera xanthina. A: Secretory cells form acini in the main venom gland, HE. B: Accessory gland were formed by tubules. Arrow point to intertubular connective tissue, dense regular connective tissue (DC), HE. C: Secondary duct joined the fang sheath, mucus secreting cells (arrow head), MT D: The main functional fang, a suture line is visible between two layers of dentine (arrow), venom canal (VC) E, F, G Remaining fangs at different stage of development, Dentine (D), Dental papilla (DP), Odontoblast (arrow head), Ameloblast (arrow).

Nine fangs at different stages of development were detected in one half of the upper jaw. Only one tooth was functional and the eight remaining fangs form a replacement series. The main functional fang contained a central canal for venom conduction (Fig 2D). In viperid, elapid and atractaspid, fangs with internal canals were reported (Kochva 1978; Kochva and Meier 1986; Wüster and Thorpe 1992). The canal of the oldest fang was empty, but in the replacement fangs the central canal was full of cells (Figs 2E, F, G). Fangs are replaced continuously throughout life in snakes. Fangs are often lost during attack, which is probably related to have a replacement series including so many teeth (Jackson 2002; Zahradnicek et al. 2008). Additionally in venomous colubrids and elapids the poison fang is attached to a stable maxillary bone, and for this reason it is always erect. In viperid snakes, the maxilla is capable of rotating. This provides the fang to be erected in the event of an attack, or laid paralel to the jaw when in the relaxed state (Kardong 1974).

On the ventral side of the tooth, an invagination was examined. As shown in figs, the venom canal was not located freely in the papilla, anchored to the outer layer by a line of dentine towards the ventral side of fang. Two odontoblasts layers secrete dentine. Dentine deposition gave rise to venom canal as the tooth develops (Figs 2D, G) like in Trimeresurus albolabris (Zahradnicek et al. 2008).

\section{CONCLUSIONS}

The current study revealed morphological and histological structure of venom apparatus in $M$. xanthina. There are many variations in venom gland design among viperids and all other venomous snakes. Therefore the results presented 
here may be common among venomous snakes and model of the viperid design of the venom gland. Additionally, our results shows that venom canal develops according to both the invagination of epithelial cells and dentine deposition.

\section{ACKNOWLEDGEMENTS}

The present study was carried out according to approved by Republic of Turkey Ministry of Food, Agriculture and Livestock (date: 03 June 2014, number: 25769). This work was supported by Ege University Research Council 2013 Grant No. Fen 007 and produced by MSc thesis of first author.

\section{REFERENCES}

Akat E, Cakici Ö, Dinçaslan YE, Arikan H. Histochemical and histological investigations on Duvernoy's gland in Natrix tessellata (Squamata: Colubridae). Kafkas Univ Vet Fak. 2011; 17(2): 285289 ,

Akat E, Arikan H, Göçmen B. Investigation of dorsal/ventral skin and the parotoid region of Lyciasalamandra billae and Lyciasalamandra luschani basoglui (Urodela: Salamandridae). Biologia. 2014a; 69(3): 389-394.

Akat E, Arıkan H, Göçmen B. Histochemical and biometric study of the gastrointestinal system of Hyla orientalis (Bedriaga, 1890) (Anura, Hylidae). Eur J Histochem. 2014b; 58: 291-295.

Başoğlu M, Baran İ. Türkiye Sürüngenleri, Kısım 2. Y1lanlar. Ege Üniversitesi Fen Fakültesi Kitaplar Serisi. 1980; 81.

Budak A, Göçmen B. Herpetoloji. Ege Üniversitesi Fen Fakültesi Kitaplar Serisi. 2005; 194.

de Oliveira L, Jared C, da Costa Prudente AL, Zaher H, Antoniazzi MM. Oral gland in dipsadine "goo-eater" snake: Morphology and histochemistry of the infralabial gland in Atractus reticulatus, Dipsas indica and Sibynomorphus mikanii. Toxicon. 2008; 51: 898-913,.

Edmund AG. Dentition. In: Gans, C., d'A Bellairs, A., Parsons, T.S. (Eds.), Biology of the Reptilia: Morphology A. Academic Press, New York., 1969.

Gans C, Kochva E. The accessory gland in the venom apparatus of viperid snakes. Toxicon. 1965; 3: 61-63,

Gennaro JF, Callahan WP, Lorincz AE. The anatomy and biochemistry of a mucus-secreting cell type present in the poison apparatus of the pit viper Ancistrodon piscivorus piscivorus. Ann NY Acad Sci. 1963; 106: 463-471.

Jackson K. How tubular venom-conducting fangs are formed. J Morphol. 2002; 252: 291-297.
Kardond KV. Kinesis of the jaw apparatus during the strike of the cottonmouth snake, Agkistrodon piscivorus. Forma Funct. 1974; 7: 327-354.

Kardong KV. Colubrid snakes and Duvernoy's "Venom" Glands. Toxin Rev. 2002; 21(1-2): 1-19.

Kim YS, Ho SB. Intestinal goblet cells and mucins in health and disease: recent insights and progress. $\mathrm{Curr}$ Gastroenterol Rep. 2010; 12: 319-330.

Kochva E, Shayer-Wollberg M, Sobol R. The special pattern of the venom gland in Atractaspis and its bearing on the taxonomic status of the genus, Copeia. 1967; 1967: 763-772.

Kochva E. Oral glands of the reptilia, Biology of the Reptilia, 1978; 8: 43-161.

Kochva E, Meier J. The fangs of Atractaspis engaddensis Haas (Serpentes: Atractaspididae). Rev. Suisse Zool. 1986; 93(3): 749-754.

Kochva E. The origin of snakes and evolution of the venom apparatus. Toxicon. 1987; 25(1): 65-106.

Lagow E, DeSouza MM, Carson DD. Mammalian reproductive tract mucins. Hum Reprod Update, 1999; 4: 280-292.

Mackessy SP. Morphology and ultrastructure of the venom glands of the Northern Pacific Rattlesnake Crotalus viridis oreganus. J Morphol. 1991; 208: 109-128.

Mackessy SP, Baxter LM. Bioweapons synthesis and storage: the venom gland of front-fanged snakes. Zool Anz. 2006; 245: 147-159.

Mackessy SP. Handbook of Venoms and Toxins of Reptiles. CRP Press. Taylor \& Francis Group. Boca Raton, London \& New York, 2010; 528 pp.

Rogers DF. The airway goblet cell. Int J Biochem Cell B. 2003; 35: 1-6.

Sakai F, Carneiro SM, Yamanouye N. Morphological study of accessory gland of Bothrops jararaca and its secretory cycle. Toxicon. 2012; 59: 393-401.

Tabak LA. In defense of the oral cavity: structure, biosynthesis, and function of salivary mucins. Annu Rev Physiol. 1995; 57: 547-564.

Young BA, Blair M, Zahn K, Marvin J. Mechanics of venom expulsion in Crotalus, with special reference to the role of the fang sheath. Anat Rec. 2001; 264: 415-26.

Young BA, Kardong KV. Mechanisms controlling venom expulsion in the western diamondback rattlesnake, Crotalus atrox. J Exp Zool. 2007; 307A: 18-27.

Wüster W, Thorpe RS. Dentitional phenomena in cobras revisited: spitting and fang structure in the Asiatic species of Naja (Serpentes: Elapidae). Herpetologica 1992; 424-434.

Zahradnicek O, Horacek I, Tucker AS. Viperous fangs: Development and evolution of the venom canal. Mech Develop. 2008; 125: 786-96. 